\title{
Legal Consequences of Refugees' Visa Misuse to Obtain Indonesian Citizenship
}

\author{
Aninda Novedia Esafrin* \\ University of Jember, Indonesia
}

Antikowati

University of Jember, Indonesia

Gautama Budi Arundhati

University of Jember, Indonesia

\begin{abstract}
This paper aims to examine problems regarding refugees' possible misuse inconsistent with Indonesia's laws and regulations. In this context, the government can make efforts to deal with refugees who enter Indonesia illegally. The government can formulate new laws and regulations in more detail, clearly and in detail, starting from the arrest process to the sanctions process obtained. Because, until now, Indonesia has not had this policy. Those refugees' status then serves to get a decent living in a recipient country such as Australia. Refugees widely use visa misuse because Indonesia implements a visa-free system of visits to 169 countries worldwide. Visa-Free Visit Policy based on President Regulation Number 125/2016 on VisaFree Visit. In this regard, the country needs to anticipate the increasing number of visa misuse for refugees entry to Indonesian territory by sending them to immigration detention centers as a form of sanctions imposed before returning to their country and making deportation the last step in resolving the visa misuse problem committed by refugees.
\end{abstract}

KEYWORDS: Misuse of Visa in Indonesia, Immigration Detention, Refugee Deportation.

Submitted: 18/04/2020 Reviewed: 12/08/2020 Revised: 12/09/2020 Accepted: 30/09/2020

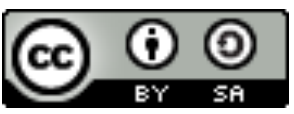

Copyright $\odot 2020$ by Author(s)

This work is licensed under a Creative Commons Attribution-ShareAlike 4.0 International License. All writings published in this journal are personal views of the authors and do not represent the views of this journal and the author's affiliated institutions

* Corresponding authors' e-mail: anindanovediaesa@gmail.com 


\section{INTRODUCTION}

The increasing number of refugee flows in Indonesia cannot be separated from refugees' visa misuse. ${ }^{1}$ Refugees move from their home country to Indonesia due to discrimination from their group or country due to ethnicity, religion, and race, causing fear and terror that threatens refugees. These factors ultimately underlie refugees to pursue a decent life in other countries. Indonesia is only used as a transit point for refugees to obtain refugee status from the UNHCR agency, responsible for granting refugee status by the 1951 Convention and 1967 Protocol provisions. The final goal of refugees to get a decent living in Australia. Australia's factor as a receiving destination country is that Australia's economy is very advanced, and Australia is a member country that signed the 1951 Convention and 1967 Protocol. ${ }^{2}$

A standard visa used by refugees to commit misuse is a free visit visa. The visa-free visit itself is a government policy to exempt visas for 169 countries to improve the Indonesian economy and increase the tourist visits of foreign nationals to Indonesia. The Visit Visa-Free Policy is regulated in Presidential Regulation Number 125/2016 on Free Visit Visas. However, the refugees responded differently to this favorable policy because refugees could quickly enter Indonesian territory without using official visas. In addition to using a visit visa-free, they can use a temporary residence permit visa to enter Indonesian territory. If the visa expires, they then overstay and request an application to make them refugees in Indonesia.

The government takes the problem of misuse of visas by refugees seriously by deporting refugees to their home country, which previously made their entry into an immigration detention center to record their identity. It aims to put that identity on the deterrence list and register as a condition for deportation. ${ }^{3}$ Deportation is the last step taken by the government to reduce the misuse by refugees. However, before the deportation, the government

1 An explanation from the United Nations High Commissioner on Refugees (UNHCR) Indonesia shows that at the end of December 2019, the number of registered refugees in Indonesia was 13,657 people from 45 countries, more than half of whom were Afghan refugees. See United Nations, "UNHCR in Indonesia" (2020), UN High Comm Refug, online: <https://www.unhcr.org/id/en/unhcr-in-indonesia> .

2 Maria Pedersen, Australia and the 1951 Refugee Convention: An Analysis of Incentives for Non-compliance (Aalborg: Aalborg University, 2016) at 5.

3 Kadarudin et al., "The Situation of International Refugee in Indonesia: A Legal Perspective" (2018) 4:1 Veritas Justitia at 13-14. 
undertook diplomatic cooperation to return to their home countries could be guaranteed their safety by their country.

This paper examines the problems resulting from the misuse of visas by refugees, not by Indonesia's laws and regulations. The government can make efforts to deal with refugees who enter Indonesia illegally. The government can formulate new laws and regulations that can discuss problems caused by refugee actions in more detail, clearly and in detail, starting from the arrest process to the sanctions process obtained. Because until now, Indonesia does not have this policy.

The writing structure will begin by discussing the state's authority to crack down on refugees' visa misuse in Indonesia. The discussion section on state authority will examine various international agreements that address visa problems for refugees from other countries. After discussing the state's authority, we will then discuss the legal consequences resulting from international refugees' misuse of visas. The discussion section on the legal consequences of the misuse of visas by refugees will describe the consequences of misusing visas in various legal actions by the Indonesian government. The paper will end with a discussion of the possible solution.

\section{THE GOVERNMENT'S RESPONSE TO VISA MISUSE}

To take action against the misuse of visas by refugees is undoubtedly not easy. The government needs several policies to support the enforcement of visa misuse by refugees. This policy is in the form of cooperation abroad.

\section{A. Overseas Cooperation in Handling the Smuggling of Refugees}

Taking cooperative action with foreign countries is a step taken by the government in dealing with refugees' problems. The cooperation between Indonesia and abroad to deal with people smuggling, especially refugees, is in Bali Process on People Smuggling, Lombok Treaty, and Operation Sovereign Border. Human smuggling involves Indonesian citizens and other citizens so that the smuggling can be said to be successful. 


\section{Bali Process on People Smuggling}

Bali Process on People Smuggling is regional cooperation in the security sector in border areas regarding people smuggling and transnational criminal acts in refugees. Several countries participating in the Bali Process on People Smuggling are countries in the Asian region. These countries, such as Japan, Thailand, South Korea, Afghanistan, Malaysia, Singapore, Turkey. International agencies participating in the collaboration are the Organization for Migration (IOM) and the United Nations High Commissioner For Refugees. The meeting between countries and international organizations resulted in a cooperation framework that deals with problems in the security, political, economic, and social fields. The cooperation is divided into three points. First, activities that do not respect national boundaries and sovereignty; second, activities that endanger immigrant human rights; and third, activities that interfere with immigration management. ${ }^{4}$

The Bali Process is a formidable challenge for refugees who are crossing borders because it puts tremendous pressure on people smuggling to reduce their intensity in crossing borders of a country. This emphasis was made to reduce the problem of people smuggling across national borders, but this is not easy because reducing smuggling intensity means eliminating all persons involved in human smuggling located within national borders.

\section{Lombok Treaty}

The Lombok Treaty is a bilateral collaboration between Indonesia and Australia. This cooperation is to maintain national security and peace in the territorial sea boundary between Indonesia and Australia. This collaboration was carried out in 2006 to maintain maritime security. However, the cooperation's main objective is related to security in the territorial boundaries of each country. The main points of the cooperation are Lombok Treaty in the defense sector by increasing cooperation on capacity building through military education, exchange, and cooperation in the field of technology; law enforcement to prevent and end criminal acts including human smuggling, money laundering, terrorist financing, corruption, fishing illegal, cybercrime, narcotics trafficking and arms trafficking and counter-terrorism by facilitating a significant and rapid response in the face of terrorist attacks

4 Nurul Azizah Zayzda dan Sri Wijayanti, "Negara Maritim Indonesia, Migrasi Tidak Teratur, dan Hak Pengungsi Lintas Batas"(2016) 3:2 Insignia: Journal of International Relations at 56. 
and by strengthening intelligence cooperation in dealing with terrorism. ${ }^{5}$ The cooperation agreement made by Indonesia and Australia further emphasizes cooperation on the boundaries of each country's territorial sea, which does not experience the threat of crimes such as people smuggling or refugees.

\section{Operation Sovereign Borders}

Operation Sovereign Borders is an operation initiated by Australia in 2013. This operation is related to the military's border security, aiming to eradicate people smuggling and protect Australia's borders. Australia has a policy in this operation: to refuse refugees who come to Australia by sea by boat or boat without using a visa or other official documents. This policy is known as the slogan, "No way, they will not make Australia home". 6

As a result of this policy, many ships or boats carrying refugees without visas and official documents were sent out of Australia's territorial borders and returned to Indonesia. So that with this policy, Indonesia felt very disadvantaged because Indonesia considered Australia to transfer the burden and responsibility of refugees to Indonesia. ${ }^{7}$ Therefore, Indonesia had the arrival of refugees who were returned by Australia, so Indonesia had difficulty finding destination countries. Moreover, Indonesia cannot repatriate or return refugees to their country of origin because Indonesia has not ratified the 1951 Convention on Refugees.

\section{B. Cooperation with International Organizations}

\section{United Nations High Commissioner for Refugees (UNHCR)}

Refugee protection is the responsibility of all countries, especially countries that have signed and ratified the 1951 Convention. Countries that have signed the 1951 Convention are legally obliged to protect refugees under the 1951 Convention provisions regardless of ethnicity, religion, country of origin, and to respect the basic principles of protection. Located among countries receiving many asylum seekers and refugees such as Malaysia,

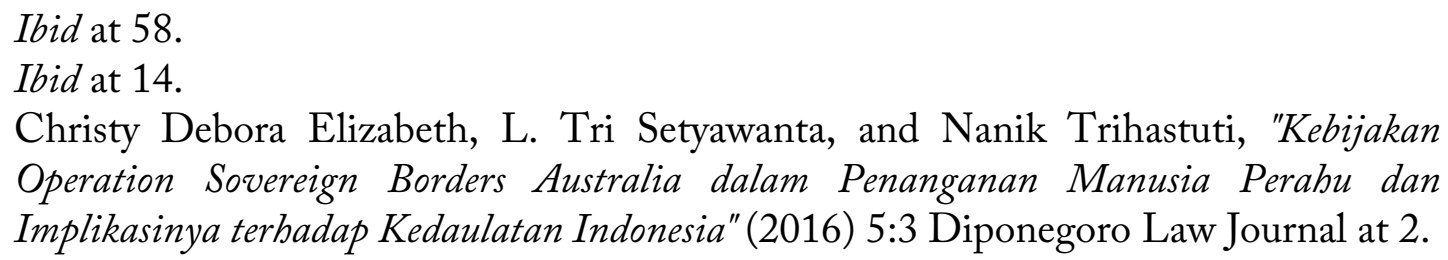


Thailand, and Australia. Indonesia is influenced by refugees' increasing movement transiting to Indonesia. It tends to result in problems in Indonesian security. Therefore, persons of particular concern and care for UNHCR are refugees under the 1951 Convention, persons who have fled conflict or serious disturbance to public order (refugees according to the definition of the OAU Convention and the Cartagena Declaration), persons who have returned to their home country (ex-refugees), stateless people and internally displaced persons. ${ }^{8}$

UNHCR assists refugees in obtaining refugee status, but not all refugees can obtain refugee status. The stages of obtaining refugee status must go through the refugee applicant registration process, followed by an initial interview and then determining the refugee status. The refugee applicant registration contains official documents containing the refugee's complete identity and why they left the country of origin. After the registration process is over, UNHCR will issue an attestation letter containing the principle of nonrefoulment. The initial interview is an interview conducted by UNHCR to scrutinize the refugee applicant's case before being recommended to accept or reject the case. The determination of refugee status is the final stage in resolving cases of refugee status requests. ${ }^{9}$

State security is certainly not easy for Indonesia to do alone. Therefore, the Indonesian Government and UNHCR collaborate to persuade refugees to be returned to their home countries without resorting to coercion. First, these methods are conducting voluntary repatriation, the process of carrying out repatriation, namely by sharing information about conditions in the country of origin and conducting interviews with refugees to ensure that they have received sufficient information. Then agree with the country of origin and country of asylum. After that, provide the necessary documentation for refugees and provide transportation to bring them back to their country. Provide material and financial assistance if refugees need money at an early stage when they return to their home country. Then, observing the refugees

8 Heru Hartono, Peran Imigrasi dalam Penanganan Pengungsi Warga Negara Asing di Kota Medan, Thesis (Medan: Fakultas Hukum Universitas Sumatera Utara) at 19.

9 The United Nations High Commissioner for Refugees (UNHCR), or the United Nations agency for refugee affairs, is a non-political humanitarian organization formed by the UN General Assembly in December 1950 and began operations on January 1, 1951. It was mandated to provide international protection to refugees and promote long-term solutions to their problems. UNHCR carries out its mandate in collaboration with governments, subject to approval by the government concerned, and with private organizations. 
who have returned to their home countries to ensure that they have received full protection from their government and participate in efforts to ensure the success of refugee reintegration. ${ }^{10}$

Second, the Indonesian government has created local settlements for refugees who are unable to return home. Local settlements were made close to local Indonesians or of local descent from the same country as refugees. It can provide benefits such as bringing in skills that can help the asylum country, creating new resources brought by refugees, the interaction between ethnic groups, local cultures, and languages and creating a sense of security. Third, placement in a third country is a placement that depends on the receiving country. So that if the receiving country wants to accept refugees in that country, the refugees can move and reside in the receiving country. If the receiving country does not wish to accept refugees, the refugees can be returned to the country of transit.

The protection function, established by the UNHCR, aims to advance the settlement and ratification of international conventions to protect refugees. It also oversees the implementation and proposes amendments, improves refugees' situation, and reduces the number of people requiring protection. Also, it aims to increase voluntary return or assimilation with the communities of new countries, increase the acceptance of refugees into within countries, and facilitate refugees' transfer of assets. It also aims to obtain information from the government regarding the number and condition of refugees in its territory and applicable laws and regulations, and maintain close relations with government and non-government organizations. Finally, it aims to establish relationships with private organizations dealing with refugee issues and facilitate private businesses. ${ }^{11}$

\section{International Organization for Migration (IOM)}

Cooperation between the Government and IOM is to assist the Indonesian government in implementing policies and implementing laws and regulations and migration mechanisms for refugees who come to Indonesia without using visas or other official documents. IOM provides training to government officials and also assists asylum seekers and refugees.

10 Joko Setiyono, "Kontribusi UNHCR dalam Penanganan Pengungsi Internasional di Indonesia" (2017) 46:3 Masalah-Masalah Hukum at 279.

11 Heru Hartono, supra note 8 at 18. 
The role of IOM in the handling of refugees in Indonesian territory is: First, providing adequate humanitarian and medical assistance to targeted immigrants; Second, respecting the fundamental rights of immigrants; Third, provide information and consultation to immigrants on various options including voluntary return; Fourth, increasing the capacity of central and local government on a sustainable basis in dealing with their internal problems; Fifth, be in a healthy condition to face the burdens and pressures of carrying out activities and be able to maintain personal safety in the field. Sixth, undergo proper financial procedures. ${ }^{12}$

\section{Association of Southeast Asian Nations (ASEAN)}

Many refugees entering Indonesia and Southeast Asian countries have made ASEAN members cooperate within handling Rohingya refugees. Rohingya refugees have not only fled to Indonesia but also to Thailand and Malaysia. This is the background of the cooperation related to refugees in the ASEAN region. The refugee problem can impact stability and security. It must be placed in the state and international organizations' priorities so that it can be resolved together immediately. In connection with Rohingya refugees' problems, some obstacles prevent ASEAN countries from working together to end the problem. The obstacle originates from one of the agreements that are the basis for ASEAN member countries' principles. The agreement in question has become the basis of the organization and is recorded in the ASEAN Charter. The basic principle applied by ASEAN is the principle of non-intervention. ${ }^{13}$

\section{Cases and Practices for Handling Refugees in Indonesia}

Indonesia has received many refugees from various countries such as Myanmar, Afghanistan, Vietnam, and Iran. This is because Indonesia is a strategic transit country in the crossings of a country. The following is an

12 Ibid at 22.

13 Muchsin Idris dan Soekotjo Hardiwinoto, "Peran ASEAN dalam Penanganan Pengungsi Pencari Suaka yang ada di Indonesia (Studi Kasus Pengungsi Robingya di Aceh)" (2016) 5:3 Diponegoro Law Journal at 7. The principle of non-intervention is a principle that guarantees recognition of member countries' sovereignty and guarantees protection from interference from a member state against the domestic politics of other member countries. 
example of a refugee case using Indonesia as a transit country and how the Indonesian government deals with these refugees.

First, refugees from Galang Island. On May 10, 1975, the capital of South Vietnam, Saigon, fell into the hands of North Vietnam, causing a conflict that led to the flow of refugees coming from Vietnam. ${ }^{14}$ Vietnamese refugees left their country due to several factors, namely the Vietnamese people's fear that the PRC would use Chinese descent people as a tool to control Vietnam. This prejudice cannot be separated from the disharmony of Vietnam-China foreign policy. Then there is racial discrimination. Children of Chinese descent are not allowed to enter schools, and Chinese people cannot work in the government. There is increasing tension between The PRC-Vietnam was due to the increasing intervention of the Vietnamese military in Cambodia, which provoked the PRC's invasion of Vietnamese territory. ${ }^{15}$

To solve the problem of refugees on Galang Island, the Indonesian government has implemented several policies. Namely the Galang Humanitarian Operation in 1996. The purpose of the operation was to accelerate the return of boat people to Galang Island. Indonesia is working with UNHCR. The handling of refugees is carried out by voluntary repatriation to their country of origin. ${ }^{16}$ Apart from voluntary repatriation, Indonesia and UNHCR have taken the following ways to persuade Vietnamese refugees to return to their home countries. First, creating a sense of love for their homeland and homesickness by placing billboards and banners in Vietnamese, which are placed in refugee camps; Second, the purchase of magazines or brochures in Vietnamese, which was imported directly from Vietnam. Third, screenings of films and interviews of former refugees from Galang Island who have been successful and working in Vietnam and contain appeals to return home. ${ }^{17}$

Second, the Rohingya refugees. Rohingya refugees are refugees from the Arakan ethnic group in the State of North Myanmar. The government and military in Myanmar ethnically marginalize the Rohingya. They are considered by the government as stateless persons and are not fully

14 Joshua Forkert, "Refugees, Orphans and A Basket of Cats: The Politics of Operation Babylift" (2012) 36:4 Journal of Australian Studies at 429-431.

15 Moh Fandik, "Penampungan Orang Vietnam di Pulau Galang 1975-1979" (2013) 1:1 Avatara, at 2.

16 Bunari, "Pulau Galang sebagai Penamungan Pengungsi Vietnam"(2017) 4:1 Seuneubok Lada: Jurnal Ilmu-Ilmu Sejarah, Sosial, Budaya dan Kependidikan, at 33.

17 Vindy Septia Anggrainy, "Perlindungan Pengungsi Lintas Batas Negara di Indonesia Menurut Hukum Internasional" (2014) 2:1 Lex Et Societatis, at 61. 
recognized as having their citizenship and residency status only temporarily. They must obtain permission before marriage, and permission can be legalized after several years of their marriage. Their movements are also restricted; they must get permission to even stop in other villages and are often prevented from getting medical treatment and education. The Rohingya in Myanmar are considered foreigners, and they are not allowed to work in any field within Myanmar's territory. ${ }^{18}$

In handling its Rohingya refugees, the Indonesian government has carried out two factors: the Indonesian government's internal factor, by improving laws and regulations to solve the refugee problem. The external factor is seeking acceptance into the receiving country so that refugees can have a better livelihood than even though Indonesia has not ratified the 1951 Convention and the 1967 Protocol. ${ }^{19}$

Third, the Timor Leste refugees (1998-2008). ${ }^{20}$ East Timorese refugees became refugees as a result of the failure of Indonesia's foreign diplomacy. It lost to Portugal's demands for a referendum in East Timor in 1999 in fulfilling Portugal's decolonization process over its former colony of Portuguese Timor. President Habibie's decision regarding unconstitutional politics offered two options without consulting or agreeing to the MPR RI and the East Timorese people regarding conflict and violence in Timor Leste. Nearly 30,000 refugees live in refugee camps in East Nusa Tenggara (NTT) Province. ${ }^{21}$

The ways of the Indonesian government in handling the Timor Leste Refugee Case are: First, the Indonesian Government conducts diplomacy with the Timor Leste Government so that East Timorese refugees return as Timorese citizens who need special protection; Second, the Government of Indonesia and the United Nations discussed the construction of a new refugee camp in Timor Leste to relocate East Timorese refugees in Indonesia

18 Syed S Mahmood et al., "The Rohingya People of Myanmar: Health, Human Rights, and Identity" (2017) 389:10081 The Lancet, at 1845.

19 Hardi Alunaza dan M. Kholit Juani, "Kebijakan Pemerintah Indonesia melalui Sekuritisasi Migrasi Pengungsi Rohingya di Aceh Tahun 2012-2015" (2017) 2:1 Indonesian Perspective, at 8.

20 IIn Karita Sakharina \& Kadarudin, Pengantar Hukum Pengungsi Interansional (Perbedaan Istilab Pencari Suaka, Pengungsi Internasional, dan Pengungsi dalam Negeri) (Yogyakarta: Deepublish, 2017) at 254.

21 The figure of 30,000 refers to refugees who wish to maintain their status as Indonesian citizens. See Cahyo Pamungkas, "Perbatasan Negara Dalam Perspektif Sosial": (2016) 15:1 Jurnal Ledalero at 169-170. 
to be precise in NTT; Third, there must be an agreement between Indonesia and the United Nations Transitional Administration in Timor Leste (UNTAET) regarding refugee locations that are managed by leaders with the direct appointment of refugees as Camp Manager; Fourth, UNTAET and other organizational bodies are not allowed to create or implement programs without coordinating with the Camp Manager to avoid political exploitation..$^{22}$

\section{LEGAL CONSEQUENCES FOR REFUGEES}

Misuse by refugees results in legal consequences that have previously been regulated in the Immigration Law. The legal consequence is that the perpetrator is placed in an immigration detention center or detention center and deportation. This is done to prevent the misuser from repeating his actions and be appropriately fostered in detention before returning to his country due to the misuse of official documents.

\section{A. Immigration Detention Center (Rudenim)}

The immigration detention center is a temporary residence or shelter as a quarantine place for immigrants, immigration criminals, and refugees who enter Indonesia illegally or do not have official documents such as visas and passports. ${ }^{23}$ People who are temporarily living in the detention center are called detainees. Rudenim's supervision is at the Directorate General of Immigration.

The main task of the Rudenim is to carry out some of the main tasks of the Ministry of Law and Human Rights in the field of detecting foreigners who violate the laws and regulations on immigration. They get immigration actions which have accepted the decision to return to their country or deportation. Apart from having the main task of assisting the Ministry of Law and Human Rights, the rudenim also has four functions, inter alia, carrying out detention, isolating and deporting tasks, carrying out repatriation tasks and making proposals to deter foreigners, implementing

22 Sakharina, supra note 20 at 258.

23 Evawani Elysa Lubis dan Try Panji Akbari, "Pola Komunikasi Pencari Suaka Asal Afghanistan dalam Berinteraksi di Rumah Detensi Imigrasi Pekanbaru, "(2016) 3:1 Jurnal Online Mahasiswa at 3. 
facilities for placing foreigners in third countries as well as implementing administrative management. ${ }^{24}$

Foreigners are placed in detention centers because they are in Indonesian territory without having a valid immigration permit. They are waiting for the process of repatriation or deportation, waiting for the Decree of the Minister of Law and Human Rights regarding objections submitted, subject to immigration action. The latter has served previous sentences and has not been able to be returned or deported.

\section{B. Deportation}

Deportation is an act of force by Immigration officials to remove foreigners from Indonesian territory due to immigration violations. ${ }^{25}$ International law recognizes that a country has the right to expel foreigners from its territory. However, international law does not provide explicit provisions on why countries can remove foreigners from their country. Moreover, a country's right to remove foreigners from its territory is limited only by international law principles.

An international legal expert, $\mathrm{O}^{\prime}$ Connell, expressed his opinion that the cause or reason for a country to expel foreigners from the country. ${ }^{26}$ First, taking action that endangers public safety. ${ }^{27}$ Second, they cannot pay for their living. ${ }^{28}$ Third, committing crimes related to prostitution. ${ }^{29}$ Fourth, suffering from infectious diseases. ${ }^{30}$ Fifth, political reasons such as espionage activities. ${ }^{31}$ Sixth, against the laws of a country and insulting the flag of a country. ${ }^{32}$

${ }_{24}$ M. Alvi Syahrin, "Penerapan Hukum Deteni Tanpa Kewarganegaraan (Stateless) yang Ditahan Lebih Dari 10 (Sepulub) Tahun di Rumah Detensi Imigrasi Jakarta,"(2017) 3:2 Fiat Justicia at 458.

25 Sihar Sihombing, Hukum Keimigrasian dalam Hukum Indonesia (Bandung: Nuansa Aulia,2013) at 61.

26 Sri Setianingsih Suwandi, "Suatu Peninjauan terhadap Masalah Deportasi dari Segi Hukum Internasional," (1977) 7:2 Jurnal Hukum \& Pembangunan at 85.

27 Ibid.

28 Ibid.

29 Ibid.

30 Ibid.

31 Ibid.

32 Ibid. 
Deportation is an action that is non-litigation in nature, which means that it is an action in the form of imposition of sanctions outside or not through a court decision. The deportation processes carried out to foreigners who violate Law Number 6/2011 on Immigration are the legal consequences of acts committed by the foreigner, which are differentiated into Pro Justitia or administrative actions in the form of deportation. An administrative process is then carried out at the Immigration Office, making a Detention Report (BAP) regarding the violated articles. BAP is an authentic note or writing, made in a particular form by an investigator or examiner by providing a dated and signed by the investigator and the suspect and the expert witnesses being examined. After all the BAP processes have been completed, the process will continue with making a Detention Administration Action in detention for 30 days at the immigration detention center. ${ }^{33}$

After that, they are put in the detention room; the stranger is put in the detention room for 30 days. Detention rooms are located in the respective regional Immigration Offices, whether in their respective regions, regencies, cities, or provinces. As a result, if foreigners commit an offense or misuse, they will be put into a detention room by the area of residence. Foreigners can be placed in a place other than the detention room when the foreigner is sick, giving birth, or is still a minor. After 30 days of being placed in the detention room, the foreigner is transferred to the immigration detention center or rudenim for ten years while waiting for the deportation process. During ten years, foreigners may be outside the detention center with the condition that they are obliged to report every six months.

Next is checking travel documents such as passports. This examination is to check the validity period of the passport. If the passport is no longer valid, they must coordinate with the representative of the country of origin of the foreigner to apply for a temporary passport. After having checked the travel documents, the ticket to leave for foreigners is also checked. Suppose persons do not have a ticket fee. In that case, they must apply for ticket fee assistance to their respective countries or international organizations such as UNHCR and IOM.

Registration is made in the statuskim section. The registration stage is carried out to verify the foreigner's identity and then conduct self-

33 Astrid Ditha, Amalia Diamantina, \& Amiek Soemarmi, "Pelaksanaan Deportasi Orang Asing di Indonesia berdasarkan Undang-Undang Nomor 6 Tahun 2011 tentang Keimigrasian (Studi Kasus Kantor Keimigrasian Jakarta Timur),"(2016) 5:2 Diponegoro Law Journal at 12. 
examination and luggage of the foreigner; if there are items deemed dangerous, the immigration officer can confiscate the goods and input data manually electronically related to confiscated goods. After the registration number is issued, fingerprints and facial photographs are taken, which will be registered in the list of deterrence or prevention. The registration number obtained is a one-time number that is inserted into the passport.

\section{The Immigration Intelligence}

The Immigration Intelligence Agency is regulated in Law Number 6/2011 on Immigration and Government Regulation, Law and Human Rights Number 30/2016 on Immigration Intelligence. The task of the Immigration Intelligence is to maintain Indonesia's sovereignty and the immigration service apparatus, law enforcement, state security, and facilitator of community welfare development. Immigration Intelligence also has functions regulated in Article 74 (2) Law No. 6/2011 on Immigration, stating that intelligence carries out an investigation, security, and data collection. The data collection process is divided into two mechanisms, open and closed. ${ }^{34}$

The open method is carried out by regularly collecting information and notes and recording every person who has been granted immigration permits. Open immigration intelligence activities can be carried out routinely or continuously, namely, information collection and investigation (Intelligence). Routine or continuous activities carried out by the Immigration Intelligence are regulated in Article 72 Law No. 6/2011, and operational or special, namely propaganda, psychological warfare..$^{35}$ Then the Immigration Intelligence collects data in private using immigration security or counterintelligence or in an open way, namely using routine and operational. Routinely or continuously closed, namely related to long-term espionage and short-term espionage and closed operations or specifically using rumors, sabotage, terror, subversion, and insurgence. ${ }^{36}$

Another way of monitoring used by immigration intelligence is by observing and examining all Indonesian citizens' activities in applying for passports and foreign citizens related to the plans and whereabouts of foreigners in Indonesia from coming to leaving Indonesia. This is emphasized in Article

34 Article 74 Law No. 6/2011 on Immigration.

35 Article 72 Law No. 6/2011 on Immigration.

36 Article 74 (2) Law No. 6/2011 on Immigration. 
68 (1) Law No. 6/2011 on Immigration, namely that the Immigration Control of Foreigners is carried out at the time of entry or exit visa applications. The granting of Stay Permits is carried out by collecting, processing, and presenting data and information, then compiling a list of names of foreigners who are subject to deterrence or prevention, supervising the presence and activities of foreigners in the territory of Indonesia after that taking photos and fingerprints, and other activities that can be legally accountable. ${ }^{37}$

The law also regulates the refusal of foreigners to enter Indonesian territory. The refusal process is carried out at every airport, seaport, and border crossings throughout Indonesia by Immigration Officials. Provisions for the refusal of foreigners who plan to enter Indonesian territory are regulated in Article 13 (1) Law No. 6/2011 on Immigration, which states that immigration officials can reject foreigners if their names are listed on the deterrence list not have valid travel documents. Moreover, if a foreigner has a fake Immigration document or does not have a visa, except those who are exempted from the obligation to have a visa, have provided incorrect information in obtaining a visa, suffer from infectious diseases that endanger public health, are involved in international crimes and transnational organized crime, including in the list of people looking to be arrested from a foreign country, involved in treason against the Government of the Republic of Indonesia or involved in a network of practices or activities of prostitution, trafficking in persons, and people smuggling. ${ }^{38}$

Foreigners who already have an Indonesian visa can also be refused entry to Indonesia if they are not on the Transportation Equipment crew list or passenger list, foreigners who do not have sufficient living costs while in Indonesia are considered for refusal to enter. ${ }^{39}$ Foreigners who are detected as endangering security or disturbing public order may also be refused entry to Indonesia. This provision has been regulated in Article 106 (2) the Regulation of the Minister of Law and Human Rights Number 44/2015 on the Procedures for Examining Indonesian Territory Entry and Exit at Immigration Checkpoints. ${ }^{40}$

\footnotetext{
Article 68 Law No. 6/2011 on Immigration.

Article 13 Law No. 6/2011 on Immigration.

Article 42 Law No. 6/2011 on Immigration.

40 Article 106 Regulation of the Minister of Law and Human Rights No. 44/2015 on the Inspection Procedures for Entry and Exit Indonesian Territory at Immigration Checkpoints.
} 
The wave of refugees entering Indonesia is vast, mostly refugees who do not use official or illegal documents. Several factors influence the wave of refugee flows. First, the driving factor for evacuation outside the country is triggered by prolonged conflict by different ethnicities, security conditions, politics, human rights, economic crises, and human smuggling. ${ }^{41}$ Second, the pull factor, namely Australia's result as an economically developed country, encourages refugees to come and seek asylum in Australia. ${ }^{42}$ Moreover, Australia is one of the countries that signed the 1951 Geneva Convention and the 1967 Protocol on refugees. Third, the model is divided into two kinds, legal and illegal. ${ }^{43}$ The legal mode is stipulated in Presidential Decree No. 125/2016 on Visa-Free Visits provided to 169 countries that have encouraged them to enter Indonesia without an entry visa for coming to Indonesia. The refugees illegally entered Indonesia, facilitated by smugglers who had previously paid a certain amount of money to enter traditional routes along the Indonesian border.

Due to the very high flow of refugees coming to Indonesia, Immigration Intelligence made a circular that regulates refugees' entry and exit in Indonesia. The circular contents, namely that immigration officers are required to refuse foreigners who enter Indonesia, not by applicable regulations. ${ }^{44}$ Foreigners who express a desire to seek asylum upon arrival in Indonesia so that they are not subject to immigration measures in the form of deportation to the territory of the country; Immigration officials have the right to contact the international organization working on refugee issues or UNHCR if there is an indication of a refugee to determine their status; If the Immigration Checkpoint (TPI) is far from the immigration officer, it is required to coordinate with the person in charge of the transportation means; Foreigners who have received protection from UNHCR as asylum seekers or refugees so that their residence permit is not questioned; Foreigners who have obtained the status of asylum seekers or refugees from UNHCR who have violated the law to be resolved in accordance with the provisions of applicable law in Indonesia; As a supervisory measure so that the Head of the Immigration Division records qualitative and quantitative data in order to monitor their presence and report it regularly to the Directorate General

${ }_{41}$ Trisapto Agung Nugroho, "Peran Intelijen Keimigrasian dalam Rangka Antisipasi Terhadap Potensi Kerawanan yang Ditimbulkan oleh Orang Asing di Wilayah Indonesia" (2018) 12:3 Jurnal Ilmiah Kebijakan Hukum.

42 Ibid.

43 Ibid.

${ }_{44}$ Heru Hartono, supra note 8 at 51. 
of Immigration; Housing and living expenses during the immigration office's research process or while the foreigner is under UNHCR protection is not borne by the immigration office.

\section{CONCLUSION}

Legal consequences for refugees who have misused a visa is by placing them in an immigration detention center after being deported. The imposition of these sanctions is regulated in Law Number 6/2011 on Immigration. Immigration agencies use immigration detention centers to accommodate foreigners misusing their entry permits to Indonesian territory by Article 83 (1) of the Immigration Law. Deportation is the next step taken by the immigration agency to impose sanctions on foreigners who misuse laws and regulations. Deportation to foreigners is carried out with diplomatic cooperation between Indonesia and the foreigner's country of origin to return home safely. The Immigration Intelligence Agency assists the state in monitoring refugees who enter Indonesia. The supervision is carried out so that refugees do not commit violations or misuse when they enter Indonesia and prevent refugees from causing problems that can endanger Indonesia's sovereignty. The Immigration Intelligence Agency can reject or accept foreigners or Indonesian citizens who will enter Indonesia based on Law Number 6/2011 on Immigration.

The government needs to update the legislation on refugees in more detail, covering refugees' entry and exit, violations, and the level of crimes committed by refugees. Because until now, there are no laws and regulations that have not been discussed in detail about refugees. Then, Indonesian citizens must also play an active role in assisting the government in overcoming refugees by reporting if refugees' behavior is suspicious. It is also essential that Indonesian citizens who stay in border areas also help maintain state security and state security officials and the Immigration Intelligence Agency, which like the front guard in the security system and monitoring foreign nationals' entry and exit to Indonesia. It is better if refugees' security systems and supervision in Indonesia's outer regions are improved to not enter Indonesia by misusing official documents such as visas. 


\section{REFERENCES}

Alunaza, Hardi \& M Kholit Juani. "Kebijakan Pemerintah Indonesia melalui Sekuritisasi Migrasi Pengungsi Rohingya di Aceh tahun 2012-2015" 2:1 Indonesian Perspective 1-17.

Anggrainy, Vindy Septia. "Perlindungan Pengungsi Lintas Batas Negara di Indonesia Menurut Hukum Internasional" (2014) 2:1 Lex Et Societatis.

Bunari, Bunari. "Pulau Galang sebagai Penamungan Pengungsi Vietnam" (2017) 4:1 Seuneubok Lada: Jurnal Ilmu-Ilmu Sejarah, Sosial, Budaya, dan Kependidikan.

Ditha, Astrid, Amalia Diamantina \& Amiek Soemarmi. "Pelaksanaan Deportasi Orang Asing di Indonesia berdasarkan Undang-Undang Nomor 6 Tahun 2011 tentang Keimigrasian (Studi Kasus Kantor Keimigrasian Jakarta Timur)" (2016) 5:2 Diponegoro Law Journal.

Elizabeth, Christy Debora, L. Tri Setyawanta \& Nanik Trihastuti. "Kebijakan Operation Sovereign Borders Australia dalam Penanganan Manusia Perabu dan Implikasinya terhadap Kedaulatan Indonesia" (2016) 5:3 Diponegoro Law Journal.

Fandik, Moh. "Penampungan Orang Vietnam di Pulau Galang 1975-1979" (2013) 1:1 Avatara.

Forkert, Joshua. "Refugees, Orphans and A Basket of Cats: The Politics of Operation Babylift" (2012) 36:4 Journal of Australian Studies.

Hartono, Heru. Peran Imigrasi Dalam Penanganan Pengungsi Warga Negara Asing di Kota Medan, Thesis (Medan: Fakultas Hukum Universitas Sumatera Utara).

Idris, Muchsin \& Soekotjo Hardiwinoto. "Peran ASEAN dalam Penanganan Pengungsi Pencari Suaka yang ada di Indonesia (Studi Kasus Pengungsi Rohingya di Aceh)" (2016) 5:3 Diponegoro Law Journal.

Kadarudin et al. "The Situation of International Refugee in Indonesia: A Legal Perspective" (2018) 4:1 Veritas Justitia.

Lubis, Evawani Elysa \& Try Panji Akbari. "Pola Komunikasi Pencari Suaka Asal Afghanistan dalam Berinteraksi di Rumah Detensi Imigrasi Pekanbaru" (2016) 3:1 Jurnal Online Mahasiswa.

Mahmood, Syed S, et al. "The Rohingya People of Myanmar: Health, Human Rights, and Identity" (2017) 389:10081 The Lancet. 
Nations, United. "UNHCR in Indonesia" (2020), online: UN High Commissioner for Refugees, online: <https://www.unhcr.org/id/en/ unher-in-indonesia>.

Nugroho, Trisapto Agung. "Peran Intelijen Keimigrasian dalam Rangka Antisipasi Terhadap Potensi Kerawanan yang Ditimbulkan oleb Orang Asing di Wilayah Indonesia" (2018) 12:3 Jurnal Ilmu Kebijakan Hukum.

Pamungkas, Cahyo. "Perbatasan Negara Dalam Perspektif Sosial": (2016) 15:1 Jurnal Ledalero.

Pedersen, Maria. Australia, and the 1951 Refugee Convention: An Analysis of Incentives for Non-compliance. (Aalborg: Aalborg University, 2016).

Sakharina, IIn Karita \& Kadarudin. Pengantar Hukum Pengungsi Interansional (Perbedaan Istilah Pencari Suaka, Pengungsi Internasional, dan Pengungsi dalam Negeri), 1st ed, (Yogyakarta: Deepublish, 2017).

Setiyono, Joko. "Kontribusi UNHCR dalam Penanganan Pengungsi Internasional di Indonesia" (2017) 46:3 Masalah-Masalah Hukum.

Sihar Sihombing. Hukum Keimigrasian dalam Hukum Indonesia, 1st ed (Bandung: Nuansa Aulia, 2013).

Suwandi, Sri Setianingsih. "Suatu Peninjauan terhadap Masalah Deportasi dari Segi Hukum Internasional" (1977) 7:2 Jurnal Hukum Pembangunan.

Syahrin, M Alvi. "Penerapan Hukum Deteni Tanpa Kerwarganegaraan (Stateless) yang Ditahan Lebih Dari 10 (Sepulub) Tahun di Rumah Detensi Imigrasi Jakarta" (2017) 3:2 Fiat Justicia.

Zayzda, Nurul Azizah \& Sri Wijayanti. "Negara Maritim Indonesia, Migrasi Tidak Teratur, dan Hak Pengungsi Lintas Batas" (2016) 3:02 Insignia: Journal of International Relations. 
144 | Legal Consequences of Refugees' Visa Misuse to Obtain Indonesian Citizenship

This page intentionally left blank 